\title{
Pengaruh Kinerja Keuangan Terhadap Return On Ssset (ROA) Bank Syariah Di Indonesia
}

\author{
Nisa Friskana Yundi \\ Heri Sudarsono \\ Fakultas Ekonomi, Universitas Islam Indonesia \\ Email: nisafriskanay@gmail.com; heri.sudarsono@uii.ac.id
}

\begin{abstract}
Abstrak
Penelitian ini bertujuan untuk menganalisis pengaruh kinerja keuangan terhadap ROA yang diukur menggunakan Return On Asset (ROA) pada Perbankan Syariah yang ada di Indonesia dalam kurun waktu 2010 sampai dengan 2016 dan membuktikan hipotesis. Penelitian ini menggunakan data sekunder yang terdiri dari 7 tahun, mulai tahun 2010 sampai dengan 2016 yang di peroleh dari OJK (Otoritas Jasa Keuangan) dan Bank Indonesia (BI), Metode analisis yang digunakan untuk penelitian ini menggunakan Vector Error Correction Model (VECM), yang terdiri dari uji stasioneritas, uji lag optimal, uji kointegrasi, uji stabilisasi, analisis impulse respons function, dan variance decomposition. Hasil analisis dari penelitian ini dalam jangka panjang CAR, FDR, NPG dan BOPO berpengaruh negative, sedangkan $D P K$ berpengaruh positif terhadap ROA. Sedangkan dalam jangka pendek CAR tidak berpengaruh, sedangkan FDR, BOPO dan DPK berpengaruh negative dan NPF berpengaruh positif terhadap ROA.
\end{abstract}

Kata kunci: Capital Adequacy Ratio (CAR), Financing To Deposit Ratio (FDR), Non Performing Financing (NPF), Biaya Operasional Pendapatan Operasional (BOPO), Dana Pihak Ketiga (DPK) dan Return On Asset (ROA).

\section{Abstract}

This study aims to analyze the effect of financial performance on profitability measured using Return On Assets (ROA) on Islamic Banking in Indonesia in the period 2010 to 2016 and prove the hypothesis. This study uses secondary data consisting of 7 years, from 2010 to 2016 obtained from Otoritas Jasa Keuangan (OJK) and Bank Indonesia (BI). The method of analysis used for this research is Vector Error Correction Model (VECM) consisting of stationary test, optimal lag test, cointegration test, stabilization test, impulse response function analysis, and variance decomposition. The analysis result of this research in long term CAR, FDR, NPG and BOPO have negative effect, while DPK have positive effect to ROA. While in short term CAR has no effect, while FDR, BOPO and DPK have negative effect and NPF have positive effect to ROA.

Keywords: Capital Adequacy Ratio (CAR), Financing To Deposit Ratio (FDR), Non Performing Financing (NPF), Operational Income Operating Cost (BOPO), Third Party Fund (DPK) and Return On Asset (ROA). 


\section{Pendahuluan}

Tingkat ROA bank menunjukkan kemampuan manajemen bank dalam mengelola pendananaan yang dimiliki untuk disalurkan pada sektor pembiayaan yang potensial dan aman. Optimalisasi laba dapat dicapai apabila bank syariah mampu memenuhi target pembiayaan sekaligus mampu meminimalir adanya pembiayaan bermasalah. ${ }^{1}$ Disamping, itu kemampuan bank syariah dalam meminimalkan beban operasional bank menjadi indikasi bank dapat memaksimalkan laba yang diharapkan. Apabila maksimalisasi laba dapat dicapai maka kinerja keuangan akan baik sehingga meningkatkan kepercayaan masyarakat kepada bank syariah. ${ }^{2}$

Penilaian kinerja keuangan bank syariah dapat diketahui melalui laporan keuangan. Laporan keuangan terdiri laporan posisi keuangan, laporan laba rugi, laporan arus kas, dan laporan ekuitas. Laporan keuangan berupa neraca memberikan informasi mengenai kondisi keuangan bank kepada pihak luar, misalnya bank Indonesia, masyarakat dan investor. Sedangkan, laporan laba rugi memberikan informasi tentang perkembangan keuangan bank kepada semua pihak, baik pemilik, manajemen bank, masyarakat, dan pihak lainnya. Informasi tentang keuangan bank dapat digunakan untuk menilai kinerja bank dalam menjalankan prinsip kehati-hatian dan ketentuan yang berlaku. ${ }^{3}$

Analisis rasio merupakan cara yang biasa digunakan untuk menganalisis kinerja keuangan suatu bank. Rasio merupakan alat

\footnotetext{
1 Setyawati, I, Suroso, S, Rambe D \& Susanti, Y, “ Peningkatan Kinerja Keuangan Melalui Manajemen Kesehatan pada Bank Syariah di Indonesia" Jurnal Ecodemica, Vol.1, No 1, 2017

2 Syawal, H, Rasio Keuangan dan Pengaruhnya Terhadap ROA pada Bank Pembiayaan Rakyat Syariah di Indonesia, Esensi: Jurnal Bisnis dan Manajemen, Vol. 7, No. 1, 2017

3 Munir, A.S, "Analisis Faktor-faktor yang Mempengaruhi Kinerja Keuangan Perbankan Syariah di Indonesia”, Jurnal Ummul Qura, Vol 9, No. 1, 2017
}

yang digunakan untuk menjelaskan hubungan tertentu antara faktor satu dengan yang lainnya dari suatu laporan keuangan. ${ }^{4}$ Rasio-rasio keuangan pada perbankan terdiri dari empat macam, yaitu rasio likuiditas atau liquidity ratio, rasio laverage/solvabilitas, rasio aktivitas atau activity ratio, dan rasio keuntungan atau profitability ratio. ${ }^{5}$

Rasio yang biasa digunakan digunkaan untuk melihat kinerja keuangan antara lain return on assets (ROA), capital adequacy ratio (CAR), financial debt ratio (FDR), non performing finance (NPF), rasio biaya operasional dengan pendapatan operasional (BOPO) dan dana pihak ketiga (DPK). (Azmy, $2018^{6}$; Lemiyana \& Litriani, $\left.2016^{7}\right)$

Rasio keuangan bank syariah selama 2010-2016 menunjukkan perkembangan yang cukup baik. Tingkat CAR berkisar 16, $25 \%$ - 25,16 \% yang bisa diartikan kemampuan bank syariah untuk menanggung pembiayaan/aktiva yang berisiko cukup aman. Hal ini disebabkan nilai CAR bank syariah masih diatas ketentuan BI sebesar $8 \%$, walaupun nilai CAR selama 6 tahun menunjukkan gejala sedikit kurang stabil. Sedangkan tingkat FDR bank syariah masih dalam batas tolerasi antara $85 \%$ dan $100 \%$. Dilihat dari tingkat FDR dari 2010 - 2016 menunjukkan manajemen bank syariah mampu memaksimalkan menyalurkan dana yang berasal dari masyrakat dalam bentuk pembiayaan pada kisaran $89,67 \%$ - 127,71 $\%$.

\footnotetext{
4 Wati, R. M \& Ngumar, "Analisis Faktor-faktor yang Mempengaruhi Kinerja Keuangan Bank Mandiri Syariah", Jurnal Ilmu dan Riset Akuntansi, Vol. 5, No.8, 2016

5

Dwijayanthy, F \& Naomi, P. Analisis Pengaruh Inflasi, BI Rate, dan Nilai Tukar Mata Uang terhadap ROA Bank Periode 20032007., Karisma., Vol. 3, No. 2, 2009

6 Azmi, A, "Analisis Pengaruh Rasio Kinerja Keuangan terhadap ROA Bank Permbiayaan Rakyat Syariah di Indonesia", Jurnal Akuntansi, Vo 12, No 1, 2018

7 Lemiyana \& Litriani, E, "Pengaruh NPF, FDR, BOPO terhadap Reurn on Asset (ROA) pada Bank Umum Syariah", IEconomic, Vol. 1, No. 1, 2016
} 
Tabel 1. Rasio Keuangan Perbankan Syariah Tahun 2010 s/d 2016

\begin{tabular}{cccccccc}
\hline $\begin{array}{c}\text { Rasio } \\
\text { Keuangan }\end{array}$ & 2010 & 2011 & 2012 & 2013 & 2014 & 2015 & 2016 \\
\hline CAR & $16,25 \%$ & $23,49 \%$ & $25,16 \%$ & $22,08 \%$ & $22,77 \%$ & $21,47 \%$ & $21,73 \%$ \\
FDR & $89,67 \%$ & $127,71 \%$ & $120,96 \%$ & $120,93 \%$ & $124,24 \%$ & $120,6 \%$ & $114,40 \%$ \\
NPF & $3,02 \%$ & $6,11 \%$ & $6,15 \%$ & $6,50 \%$ & $7,89 \%$ & $8,20 \%$ & $8,63 \%$ \\
BOPO & $80,54 \%$ & $76,31 \%$ & $80,02 \%$ & $80,75 \%$ & $87,79 \%$ & $88,09 \%$ & $87,09 \%$ \\
DPK & $87,4 \%$ & $87,4 \%$ & $87,29 \%$ & $88,17 \%$ & $89,88 \%$ & $87,34 \%$ & $88,31 \%$ \\
\hline
\end{tabular}

Sumber: Otoritas Jasa Keuangan (OJK)

Tingkat NPF menunjukan kemampuan bank syariah dalam mengelolaan pembiayaan bermasalah atau pembiayaan macet. Tingkat NPF di tahun 2015 dan 2016 lebih dari 8\%, keadaan ini menunjukkan manajemen bank syariah belum mampu mengelola pembiayaan yang disalurkan kepada masyarakat sesuai target yang ditentukan. Di samping itu, besarnya tingkat NPF pada tahun 2015 dan 2016 dipengaruhi tingginya pembiayaan yang disalurkan bank syariah di tahun 2014. Sedangkan kemampaun manajemen bank syariah dalam memanfaatkan dana secara efisien dapat di lihat dari tingkat BOPO.

Tingkat BOPO cenderung mengalami kenaikan selama periode 2010-2016. Kenaikan BOPO ini dipengaruhi oleh dampak ekspansi yang berupa pendirian beberapa kantor bank syariah di beberapa daerah. Pendirian kantor-kantor baru menyebabkan meningkatnya biaya-biaya operasional bank. Namun, seiring dengan peningkatan BOPO, tingkat DPK menunjukkan trend yang meningkat. Keadaan ini menunjukkan manajemen bank mampu memanfaatkan jumlah kantor yang semakin bertambah untuk menangkap potensi pendanaan masyarakat di daerah baru.

Beberapa penelitian yang mengkaji pengaruh kinerja keuangan dan ROA bank syariah menunjukkan hasil yang beragam. CAR menunjukan kemampuan bank dalam menyediakan dana untuk menanggung risiko dari setiap pembiayaan atau aktiva produktif yang berisiko. Oleh karenanya semakin tinggi CAR maka akan meningkatkan kemampuan bank dalam menghasilkan laba.
Seperti halnya dalam penelitian Rida dan Yuma (2008) ${ }^{8}$, Lutfiyah dan Dina (2015) ${ }^{9}$, Astohar (2016) ${ }^{10}$, Layaman dan Qoonitah Fitri Al-Nisa (2016) ${ }^{11}$ menemukan pengaruh positif antara CAR dengan ROA. Namun dalam penelitian Ummah dan Suprapto $(2015)^{12}$, Linda dan Dina $(2015)^{13}$, Ningsukma dan Haqiqi (2016) ${ }^{14}$ yang menunjukkan bahwa CAR tidak berpengaruh terhadap ROA bank Syariah. Sedangkan dalam penelitian Farrashita dan Prasetiono (2016) ${ }^{15}$ menemukan adanya pengaruh negatif CAR terhadap profitabiltas bank Syariah.

FDR adalah rasio pembiayaan yang disalurkan bank dengan dana yang diterima oleh bank. Apabila FDR meningkatkan maka akan meningkatkan kemampuan bank dalam memanfaat dana untuk menghasilkan laba

\footnotetext{
${ }^{8}$ Rida \& Yuma, "Analisa Efisiensi Operasional terhadap ROA pada Bank Umum Syariah dan Unit Usaha Syariah pada BSM dan BNI Syariah," Jurnal Bisnis dan Manajemen, Vol. 4, No. 3, 2008

9 Lutfiyah dan Dina, "Pengaruh Pertumbuhan Dana Pihak Ketiga Terhadap Laba Perbankan Syariah di Indonesia", JESTT, Vol.2 No.8, 2015

10 Astohar, "Pengaruh CAR dan FDR terhadap ROA Perbankan Syariah di Indonesia dengan Inflasi sebagai Variabel Pemoderasi”, Among Makarti, Vol. 9, No. 18, 2016

${ }^{11}$ Layaman dan Qoonitah Fitri Al-Nisa. "Analisis Pengaruh Capital Adequacy Ratio (Car) Dan Financing To Deposit Ratio (Fdr) Terhadap Profitabilitas Bank Syariah." Al-Amwal: Jurnal Ekonomi dan Perbankan Syari'ah 8.1 (2016).

${ }^{12}$ Ummah \& Suprapto, "Faktor-Faktor Yang Mempengaruhi ROA Pada Bank Muamalat Indonesia", Jurnal Ekonomi dan Perbankan Syariah, Vol. 3. No.2, 2011

${ }^{13}$ Linda \& Dina, "Pengaruh CAR, NPF, FDR, dan ROE terhadap ROA pada Bank Pembiayaan Rakyat Syariah di Indonesia Periode Januari 2009 hingga Mei 2014," JEST, Vol. 2, No. 12,2015

${ }^{14}$ Ningsukma \& Haqiqi, "Pengaruh Internal CAR, FDR dan BOPO dalam Peningkatan ROA Industri Bank Syariah di Indonesia," Jurnal Aplikasi Manajemen, Vol. 14, No.1, 2016

${ }^{15}$ Farrashita \& Prasetiono, "Pengaruh CAR, FDR, NPF dan BOPO terhadap ROA (ROE) pada Bank Umum Syariah di Indonesia," Diponegoro Journal of Management, Vol. 5, No. 1, 2016
} 
atau meningkatkan ROA. Namun, apabila bank tidak mampu mengoptimalkan dana yang dimiliki untuk disalurkan dalam pembiayaan maka ROA bank menurun. Hubungan antara FDR dengan ROA dapat lihat dari penelitian Rida dan Yuma (2008) ${ }^{16}$, Ningsukma dan Haqiqi (2016) ${ }^{17}$, Farrashita dan Prasetiono $(2016)^{18}$, Layaman dan Qoonitah Fitri Al-Nisa (2016) ${ }^{19}$ menunjukan pengaruh negatif antara FDR dengan ROA. Sedangkan dalam penelitian Ummah dan Suprapto $(2015)^{20}$ menemukan FDR tidak berpengaruh terhadap tingkat ROA bank syariah.

NPL diukur dari rasio perbandingan antara pembiayaan bermasalah terhadap total pembiayaan yang diberikan. Apabila manajemen bank dalam mengelolaan pembiayaan kurang baik akan berdampak pada meningkatknya jumlah pembiayaan bermasalah. Meningkatnya pembiayaan bermasalah akan menurunkan kemampuan bank dalam menghasilkan laba bank. Hubungan negatif antara NPL dengan ROA bank syariah ditunjukkan oleh penelitian Mawaddah (2015), Farrashita dan Prasetiono (2016), Almunawwaroh \& Marliana (2018). Namun, dalam penelitian Ummah dan Suprapto (2015), Linda dan Dina (2015) menunjukkan bahwa NPF tidak berhubungan dengan ROA. Sedangkan Rida dan Yuma (2008) menunjukan pengaruh positif antara NPF dengan ROA

Rasio biaya operasional terhadap pendapatan operasional (BOPO) merupakan rasio yang digunakan untuk mengukur kemampuan manajemen bank dalam memanfaatkan pendapatan operasional untuk menutup biaya operasional bank. Apabila BOPO meningkat maka akan meningkatkan biaya operasional relatif terhadap pendapatan bank sehingga menurunkan kemampuan manajemen bank dalam mengoptimalkan pendapatan yang diperoleh. Penelitian Azmi,

\footnotetext{
${ }^{16}$ ibid

${ }^{17}$ ibid

${ }^{18} \mathrm{ibid}$

${ }^{19}$ ibid

${ }^{20}$ ibid
}

A (2018), Lemiyana \& Litriani (2016), Farrashita dan Prasetiono (2016), Ubadillah (2016), Muliawati \& Khoiruddin (2015) menunjukkan pengaruh negatif antara BOPO dengan ROA. Sedangkan dalam penelitian Rida dan Yuma (2008) menunjukkan pengaruh positif

Dana Pihak Ketiga (DPK) telah dijelaskan dalam Undang-Undang Nomor 10 Tahun 1998 tentang Perbankan (UU Perbankan) yang dimana yang dimaksut dengan DPK adalah dana yang dipercayakan masyarakat kepada bank berdasarkan perjanjian penyimpanan dana dalam bentuk giro, deposito, sertifikat deposit, tabungan atau bentuk lainnya. Semakin tinggi DPK maka akan meningkatkan kemampuan manajemen bank syariah untuk menyalurkan dananya dalam bentuk pembiayaan. Meningkatnya pembiayaan akan menambah kemampuan bank dalam menghasilkan ROA. Lutfiyah dan Dina (2015) menemukan pengaruh positif antara DPK dengan ROA. Sedangkan Sudarsono (2017) menemukan adanya hubungan negative antara DPK dengan ROA bank syariah. Pada penelitian Husaeni (2017) dan Nurhasanah (2014) menunjukkan tidak ada hubungan antara DPK dengan ROA bank Syariah

\section{Metode Penelitian}

Penelitian ini mengunakan metode penelitian kuantitatif karena didalam menganalisis mengunakan perhitungan yang berdasarkan data-data nominal. Data yang digunakan adalah data sekunder yang diambil dari wibesite data statistik Otoritas Jasa Keuangan (OJK). Data yang digunakan adalah data time series dari Januari 2010 sampai Desember 2016. Adapun digunakan data bulana dari tahun 2010 sampai 2016 dikarenakan kelengkapan data pada masingmasing variabel. Sedangkan variabel yang digunakan dalam penelitian ini antara lain ROA, CAR, FDR, NPL, BOPO dan DPK.

Penelitian ini mengunakan uji unit root test untuk mengetahui regresi palsu dikarenakan data tidak stasioner. Suatu data tidak stasioner apabila nilai rata-rata 
variansya tidak konstan sepanjang waktu. Kemudian dilakukan uji kointegrasi dengan mengunakan uji Johanes untuk mengetahui jumlah kointegrasi kelompok vector. Uji kointegrasi untuk mengetahui stasioner dalam residual regresi dalam persamaan. Apabila ada kointegrasi antara variabel ROA, CAR, FDR, NPL, BOPO dan DPK maka dapat diuji dengan model vector error correction model (VECM). VECM dapat mengetahui hubungan antar variabel dalam jangka panjang dan jangka pendek. Adapun model VECM dapat disusun sebagai berikut:

$$
\begin{aligned}
\Delta R O A_{t} & =a_{1}+\beta_{t}\left(e_{t-1}\right)+a_{1, i} \Delta R O A_{t-1}+b_{1, i} \\
\Delta C A R_{t-1} & +c_{1, i} \Delta F D R_{t-1}+d_{1, i} \Delta N P F_{t-1} \\
& +e_{1, i} \Delta B O P O_{t-1}+f_{1, i} \Delta D P K_{t-1}+\varepsilon_{1 t}
\end{aligned}
$$

dimana $R O A$ adalah ROA; $\beta_{1} \sim \beta_{8}$ adalah tingkat penyesuaian parameter, yaitu faktor penyesuaian koreksi kesalahan jangka panjang; $e_{\mathrm{t}-1}$ adalah syarat kesalahan pra koreksi; CAR adalah capital adequacy ration; FDR adalah financing to deposit rasio; $N P F$ adalah non performing finance; BOPO adalah rasio beban operasional dengan pendapatan operasional; $D P K$ adalah dana pihak ketiga; $\varepsilon_{1 t}$ adalah white noise.

Analisis impulse response function (IRF) dan variance decomposition (VD) dilakukan untuk mengetahui goncangan variabel ROA, CAR, FDR, NPF, BOPO dan DPK terhadap ROA Dengan IRF dapat diketahui berapa lama pengaruh goncangan suatu variabel terhadap ROA. Selain itu, IRF dapat mengetahui variabel manakah yang akan memberi respon terbesar terhadap adanya goncangan. Sedangkan analisis VD untuk mengetahui tingkat kontribusi suatu variabel terhadap perubahan variabel itu sendiri dan variabel lainnya pada beberapa periode masa datang.

\section{Hasil Penelitian}

\section{Uji Stasioner}

Berdasarkan hasil uji stasioner menunjukkan bahwa ROA, FDR dan DPK stasioner di level sedangkan CAR, NPF, BOPO diketahui tidak stasioner di tingkat level. Untuk menghindari persoalan regresi lancung maka perlu uji akar unit untuk mentransformasi dari hasil uji yang tidak stasioner menjadi stasioner. Melalui proses differensi data dengan uji integrasi atau uji ADF dihasilkan keadaan first difference. Tabel 2 menunjukkan hasil uji ADF tingkat level dan first different, dimana setelah melalui transformasi data menghasilkan data stasioner pada $\alpha=1 \%$.

Tabel 2. Hasil Uji ADF Menggunakan Intercept pada Tingkat Level dan First Different

\begin{tabular}{lrrlrcl}
\hline \multicolumn{1}{c}{ Variabel } & \multicolumn{3}{c}{ Level } & \multicolumn{3}{c}{ First Different } \\
\cline { 2 - 7 } & $\begin{array}{r}\text { ADF t- } \\
\text { statistik }\end{array}$ & Prob & Keterangan & $\begin{array}{c}\text { ADF t- } \\
\text { statistik }\end{array}$ & Prob & Keterangan \\
ROA & -3.316851 & 0.0172 & Stasioner & -9.332053 & 0.0000 & Stasioner \\
CAR & -2.334051 & 0.1639 & Non Stasioner & -8.374205 & 0.0000 & Stasioner \\
FDR & -2.970064 & 0.0420 & Stasioner & -10.32014 & 0.0000 & Stasioner \\
NPF & -0.706616 & 0.8387 & Non Stasioner & -9.592989 & 0.0000 & Stasioner \\
BOPO & -1.888591 & 0.3361 & Non Stasioner & -14.66729 & 0.0000 & Stasioner \\
DPK & -8.878629 & 0.0000 & Stasioner & -10.71693 & 0.0001 & Stasioner \\
\hline
\end{tabular}

\section{Uji Lag Optimal}

Uji lag optimal dilakukan untuk mengetahui tegang waktu data yang sesuai untuk diamati dalam proses regresi. Penentuan lag optimal digunakan kriteria informasi yang sudah tersedia di dalam proses uji VECM, seperti kriteria likehood ratio (LR), final prediction error (FPE), akaike information criterion (AIC), shwarz information criterion (SC), dan hannan-quin criterion (HQ). Dari hasil uji lag yang ditunjukkan pada tabel 3, bisa dirtikan bahwa panjang lag optimal terletak pada lag 1. dikarenakan nilai SC dan HQ terkecil diantara lag yang lainnya. 
Tabel 3. Hasil Pengujian Panjang Lag

\begin{tabular}{ccccccc}
\hline $\begin{array}{c}\text { Panjang } \\
\text { Lag }\end{array}$ & LogL & LR & FPE & AIC & SC & HQ \\
\hline $\mathbf{0}$ & -1756.763 & NA & $5.64 \mathrm{e}+12$ & 46.38849 & 46.57250 & 46.46203 \\
$\mathbf{1}$ & -1583.655 & 314.3273 & $1.53 \mathrm{e}+11^{*}$ & $42.78039^{*}$ & $44.06843^{*}$ & $43.29516^{*}$ \\
$\mathbf{2}$ & -1565.271 & 30.47809 & $2.48 \mathrm{e}+11$ & 43.24398 & 45.63605 & 44.19997 \\
$\mathbf{3}$ & -1531.972 & 49.94837 & $2.79 \mathrm{e}+11$ & 43.31506 & 46.81116 & 44.71227 \\
$\mathbf{4}$ & -1512.757 & 25.78931 & $4.73 \mathrm{e}+11$ & 43.75676 & 48.35689 & 45.59519 \\
$\mathbf{5}$ & -1493.471 & 22.83897 & $8.53 \mathrm{e}+11$ & 44.19660 & 49.90076 & 46.47626 \\
$\mathbf{6}$ & -1465.802 & 28.39709 & $1.35 \mathrm{e}+12$ & 44.41583 & 51.22403 & 47.13672 \\
$\mathbf{7}$ & -1428.154 & 32.69391 & $1.86 \mathrm{e}+12$ & 44.37248 & 52.28470 & 47.53459 \\
$\mathbf{8}$ & -1331.959 & $68.34907^{*}$ & $6.62 \mathrm{e}+11$ & 42.78840 & 51.80466 & 46.39173 \\
\hline
\end{tabular}

\section{Uji Kointegrasi}

Uji kointegrasi dilakukan untuk mengetahui hubungan jangka panjang variabel ROA, CAR, CAR, FDR, NPF, BOPO dan DPK. Berdasarkan tabel 4 terdapat tiga persamaan yang terkointegrasi, hal tersbut dapat diamati saat nilai trace statistic > critical value. dengan kata lain, variabel-variabel yang digunakan memiliki hubungan dalam jangka panjang antara satu dengan yang lainnya.

Tabel 4. Hasil Uji Kointegrasi (Johansen's Cointegration Test)

\begin{tabular}{ccccc}
\hline $\begin{array}{c}\text { Hypothesized } \\
\text { No. of CE }(s)\end{array}$ & Eigenvalue & Trace Statistic & $\begin{array}{c}\text { 0.05 Critical } \\
\text { Value }\end{array}$ & Prob. ** \\
\hline None * & 0.419313 & 129.0940 & 95.75366 & 0.0000 \\
At most 1 * & 0.366073 & 85.06700 & 69.81889 & 0.0019 \\
At most 2 * & 0.246055 & 48.14548 & 47.85613 & 0.0469 \\
At most 3 & 0.168283 & 25.26819 & 29.79707 & 0.1521 \\
At most 4 & 0.103287 & 10.34289 & 15.49471 & 0.2553 \\
At most 5 & 0.018498 & 1.512336 & 3.841466 & 0.2188 \\
\hline
\end{tabular}

\section{Uji Stabilisasi VAR}

Uji stabilitas digunakan untuk mengetahui stabil atau tidaknya suatu model. Sebuah model dikatakan mempunya stabilitas yang tinggi jika inverse akar karakteristiknya berada dalam lingkaran atau mempunyai modulus tidak lebih dari satu. Tabel 5 menunjukkan nilai modulus pada model berkisar antara $0.2090-0.9856$ atau masuk dalam lingkaran. Kondisi ini menunjukkan bahwa model VAR stabil sehingga bisa dilakukan uji impulse response dan variance decomposistion pada model ini.

Tabel 5. Hasil Uji Stabilitas VAR

\begin{tabular}{ll}
\hline \multicolumn{1}{c}{ Root } & \multicolumn{1}{c}{ Modulus } \\
\hline $\mathbf{0 . 9 8 5 6 0 0}$ & 0.985600 \\
$\mathbf{0 . 6 4 0 0 5 9}-\mathbf{0 . 1 3 5 9 6 0 i}$ & 0.654339 \\
$\mathbf{0 . 6 4 0 0 5 9}+\mathbf{0 . 1 3 5 9 6 0 i}$ & 0.654339 \\
$\mathbf{0 . 5 4 7 1 1 7}$ & 0.547117 \\
$\mathbf{- 0 . 3 4 8 4 0 4}$ & 0.348404 \\
\hline
\end{tabular}




\begin{tabular}{ll}
\hline $\mathbf{0 . 1 1 6 0 5 8}-\mathbf{0 . 3 2 4 1 6 9 i}$ & 0.344318 \\
\hline $\mathbf{0 . 1 1 6 0 5 8}+\mathbf{0 . 3 2 4 1 6 9 i}$ & 0.344318 \\
\hline $\mathbf{- 0 . 1 3 8 2 0 1} \boldsymbol{- ~ 0 . 2 9 6 8 9 3 i}$ & 0.327482 \\
\hline $\mathbf{- 0 . 1 3 8 2 0 1}+\mathbf{0 . 2 9 6 8 9 3 i}$ & 0.327482 \\
\hline $\mathbf{0 . 1 1 1 0 5 3}-\mathbf{0 . 1 7 7 1 6 8 i}$ & 0.209096 \\
\hline $\mathbf{0 . 1 1 1 0 5 3}+\mathbf{0 . 1 7 7 1 6 8 i}$ & 0.209096 \\
\hline
\end{tabular}

\section{Uji Kausalitas Granger}

Uji kualitas Granger ini dilakukan bertujuan untuk mengetahui hubungan kausalitas antar variabel dalam model yang akan diestimasi. Apabila hasil yang muncul nilai ROA lebih besar dati critical value maka antar variabel berarti tidak ada hubungan kausalitas yang terjadi. Tabel 6 menunjukkan bahwa nilai probabilitas masing-masing persamaan kausalitas di atas $5 \%$. Keadaan ini menunjukan bahwa tidak ada hubungan sebab-akibat diantara ROA, CAR, FDR, NPF, BOPO dan DPK.

Tabel 6. Hasil Uji Kausalitas Granger

$$
\text { Null Hypothessis: }
$$

ROA does not Granger Cause BOPO

$\mathrm{R}$

BOPO does not Granger Cause ROA

OA tidak ROA does not Granger Cause CAR memiliki

hubungan

sebab

akibat

dengan

CAR,

FDR,

NPF, BOPO dan DPK. Artinya keberadaan masing-masing tidak memiliki ketergantungan antara satu dengan yang lain, tingkat ROA tidak dipengaruhi CAR, FDR, NPF, BOPO dan DPK ataupun sebaliknya. ROA sebagai memiliki independensi terhadap variabel yang lain sehingga manajemen bank syariah tidak bisa terlalu memprioritas untuk mempengaruhi salah satu variabel atau variabel tertentu untuk mempengaruhi tingkat ROA. Manajemen bank syariah bisa mempengaruhi ROA apabila kebijakan tersebut secara komprehensif mempengaruhi CAR, FDR, NPF, BPO dan DPK. Adapun variabel yang berpengaruh terhadap tingkat ROA dapat dilihat dari hasil uji VECM
Obs

\begin{tabular}{cc}
\multicolumn{2}{c}{ Lag1 } \\
\hline F-Statistic & Prob \\
0.00425 & 0.9482 \\
1.45146 & 0.2318 \\
0.67934 & 0.4123 \\
1.59050 & 0.2109 \\
0.79095 & 0.3765 \\
0.00069 & 0.9790 \\
0.73259 & 0.3946 \\
0.61163 & 0.4365 \\
2.66098 & 0.1068 \\
2.58953 & 0.1115 \\
\hline
\end{tabular}

\section{Uji Vector Error Correction Model} (VECM)

VECM dapat mengetahui hubungan jangka panjang dan dinamisasi jangka pendek variabel-variabel CAR, FDR, NPF, BOPO dan DPK agar sesuai ke dalam hubungan kointegrasinya. Tabel 7 merupakan perkembangan ROA dari hasil estimasi VECM yang memperlihatkan hubungan antar variabel pada jangka panjang. Dari $t$ statistika dapat diketahui bahwa semua variabel yang mempengaruhi ROA dalam jangka panjang. Sementara itu CAR, FDR dan NPF pada lag-1 berpengaruh negatif terhadap tingkat ROA. Di lain pihak, BOPO dan DPK pada lag-1 menunjukkan hubungan positif terhadap tingkat ROA.

Tabel 7. Hasil Estimasi VECM Jangka Panjang

\begin{tabular}{cccc}
\hline Variabel & Koefisien & T Statistik & Keterangan \\
\hline CAR(-1) & -0.096828 & {$[-1.69763]$} & Signifikan \\
FDR(-1) & -0.000533 & {$[-3.99391]$} & Signifikan \\
\hline
\end{tabular}




\begin{tabular}{cccl}
\hline NPF(-1) & -0.202852 & {$[-2.06600]$} & Signifikan \\
BOPO(-1) & 0.002643 & {$[6.97769]$} & Signifikan \\
DPK(-1) & 0.102777 & {$[2.45377]$} & Signifikan \\
\hline
\end{tabular}

Tingkat CAR berpengaruh negatif terhadap tingkat ROA yang bisa diartikan bahwa kenaikan 1\% CAR akan mempengaruhi turunnya ROA sebesar $-0.0968 \%$. Kemampuan manajemen bank syariah dalam mengelola kecukupan modal cukup baik terbukti dengan nilai CAR selama tahun 2010-2016 stabil di atas 8\%. Sedangkan ROA cenderung meningkatkan setiap tahunnya walaupun kenaikan setiap bulannya menunjukkan trend yang tidak konsisten. Kenyataan ini menunjukkan bahwa peran CAR dalam mempengaruhi kenaikan ROA tidak begitu berpengaruh dalam arti rata-rata CAR bank syariah sudah mencukupi namun CAR bukan menjadi variabel yang tidak begitu dipertimbangkan bagi manajemen bank syariah untuk meningkatkan ROA. Hasil ini sesuai dengan penelitian Farrashita dan Prasetiono (2016) menemukan adanya pengaruh negatif CAR terhadap ROA bank Syariah

Tingkat FDR menceriminkan kemampuan manajemen bank syariah dalam menyalurkan pendanaan ke pembiayaan. Semakin tinggi pembiayaan bank diharapkan akan meningkatkan jumlah pendapatan bank atau ROA. Apabila kenaikan FDR mempengaruhi turunnya besaran ROA menunjukkan bahwa manajemen bank syariah tidak mampu mengelola dana yang dimiliki untuk menghasilkan keuntungan dari pembiayaan. Hasil uji jangka panjang menunjukkan FDR berhubungan negatif terhadap ROA, dimana kenaikan 1\% FDR mempengaruhi turunnya nilai ROA sebesar $0.00053 \%$. Hasil penelitian ini sama dengan penelitian Rida dan Yuma (2008), Ningsukma dan Haqiqi (2016), Farrashita dan Prasetiono (2016), Layaman dan Qoonitah Fitri Al-Nisa (2016) menemukan pengaruh negatif antara FDR dengan ROA.

Hasil regresi jangka panjang dari VECM menunjukkan bahwa NPF berpengaruh negatif terhadap besaran ROA, dimana kenaikan 1\% NPF menurunkan ROA sebesar $-0.202852 \%$. Hal ini dipengaruhi oleh kebijakan bank syariah dalam menyalurkan pembiayaan yang berorientasikasi bukan semata-mata untuk memenuhi target laba. Prinsip pembiayaan pada bank syariah bukan hanya karakter, kapasitas, jaminan, modal dan situasi namun juga kesesuaian dengan prinsip syariah. Prinsip syariah menekankan bahwa pembiayaan berdasarkan pada prinsip bagi hasil atau jual beli dimana uang berfungsi sebagai alat transaksi, bukan barang yang bisa diperjualbelikan. Pengaruh negatif antara NPF terhadap ROA bank syariah ini relevan dengan hasil penelitian Mawaddah (2015), Farrashita \& Prasetiono (2016), dan Almunawwaroh \& Marliana (2018).

Dari hasil regresi jangka panjang diketahui bahwa bila kenaikan tingkat BOPO sebesar 1\% BOPO akan meningkatkan ROA sebesar $0.002643 \%$. Hasil positif ini sesuai dengan penelitian Sudarsono (2017) dan Rida \& Yuma (2008). Selama 2010-2016 beberapa kantor cabang dan cabang pembantu bank syariah di bangun dibeberapa daerah sehinggga mempengaruhi besaran biaya penyediaan pegawai dan fasilitas kantor. Namun bertambahnya kenaikan jumlah kantor ini memperluas segmen pasar di beberapa daerah yang belum terjangkau oleh pelayanan bank syariah. Keadaan ini yang menjadikan peningkatan BOPO diikuti oleh peningakatan pendanaan dan pembiayaan bank syariah. Hubungan positif antara BOPO dengan ROA bisa diartikan bahwa manajemen bank syariah mampu menjaga efisiensi guna memaksimal tingkat ROA.

Dari hasi regresi jangka panjang menunjukkan DPK berpengaruhi positif terhadap kenaikan ROA, bila ada kenaikan DPK sebesar 1\% maka ROA akan naik sebesar $\quad 0.102777 \%$. Kenyataan ini menunjukkan bahwa manajemen bank 
syariah mampu mengoptimalkan dana yang berasal dari tabungan, deposoito dan giro untuk disalurkan dalam bentuk pembiayaan. Semakin tinggi pembiayaan akan meningkatkan kemampuan bank dalam menghasilkan pendapatan dari bagi hasil atau margin. Peningkatan pendapatan akan mempengaruhi tingkat rasio pendapatan terhadap asset bank atau ROA. Hasil ini sama dengan penelitian Lutfiyah dan Dina (2015) yang menemukan pengaruh positif antara DPK dengan ROA.

Dalam jangka pendek koefisien persamaan kointegrasi sebesar 0.072847 signifikan pada $\alpha=1 \%$, Nilai ini bermakna bermakna bahwa setiap bulan kesalahan dikoreksi sebesar $0.072847 \%$ menuju target optimal ROA.

Tabel 7. Hasil Estimasi VECM Jangka Pendek

\begin{tabular}{ccc}
\hline Variabel & Koefisien & T Statistik \\
\hline CointEq1 & 0.072847 & {$[1.31983]$} \\
D(ROA(-1)) & -0.200294 & {$[-1.63430]$} \\
D(CAR(-1)) & -0.036679 & {$[-0.27943]$} \\
D(FDR(-1)) & -0.253792 & {$[-1.91065]$} \\
D(NPF(-1)) & 0.012081 & {$[0.08438]$} \\
D(BOPO(-1)) & -0.148220 & {$[-1.32472]$} \\
D(DPK(-1)) & -0.487940 & {$[-3.77589]$} \\
C & 0.008798 & {$[0.22930]$} \\
\hline
\end{tabular}

Nilai kointegrasi sebesar 0.072847 siqnifikan pada tingkat $1 \%$ menunjukkan adanya mekanisme penyesuaian dari jangka pendek menuju jangka panjang. Pada persamaan jangka pendek diketahui variabel yang mempengaruhi tingkat ROA dalam jangka pendek adalah ROA lag 1; dan FDR lag-1; DPK lag-1, sementara CAR, NPF dan BOPO tidak berpengaruh secara signifikan. Berbeda dengan jangka panjang dimana NPF berhubungan negatif tetapi dalam jangka pendek berhubungan positif. Sedangkan BOPO dan DPK dalam jangka panjang positif tetapi dalam jangka pendek menunjukkan pengaruh negatif. Untuk lebih memperjelas hubungan antara ROA, CAR, FDR, NPF, BOPO dan DPK terhadap ROA dalam jangka panjang dan jangka pendek dapat disimak pada analisis impulse response dan variance decomposition.

\section{IRF (Impulse Response Function)}

Dalam IRF diketahui suatu gambar terdiri dari garis verikal dan horizontal, dimana vertikal menunjukkan standar deviasi untuk mengukur tingkat respon yang akan diberikan oleh CAR, FDR, NPF, BOPO dan DPK apabila terjadi goncangan terhadap ROA. Sedangkan, sumbu horizontal menunjukkan lamanya waktu respon jika ada goncangan pada ROA. Bila respon ROA di atas sumbu horizontal menunjukkan bahwa goncangan akan memberikan pengaruh yang positif. Sebaliknya apabila respon ROA dibawah sumbu horizontal menunjukkan bahwa goncangan berpengaruh negatif. Gambar 3 menunjukkan respon ROA terhadap variabel ROA, CAR, FDR, NPF, BOPO dan DPK. 
Gambar 1. Analisis IRF (Impluse Response Function) Response to Cholesky One S.D. Innovations Response to Cholesky One S.D. Innovations
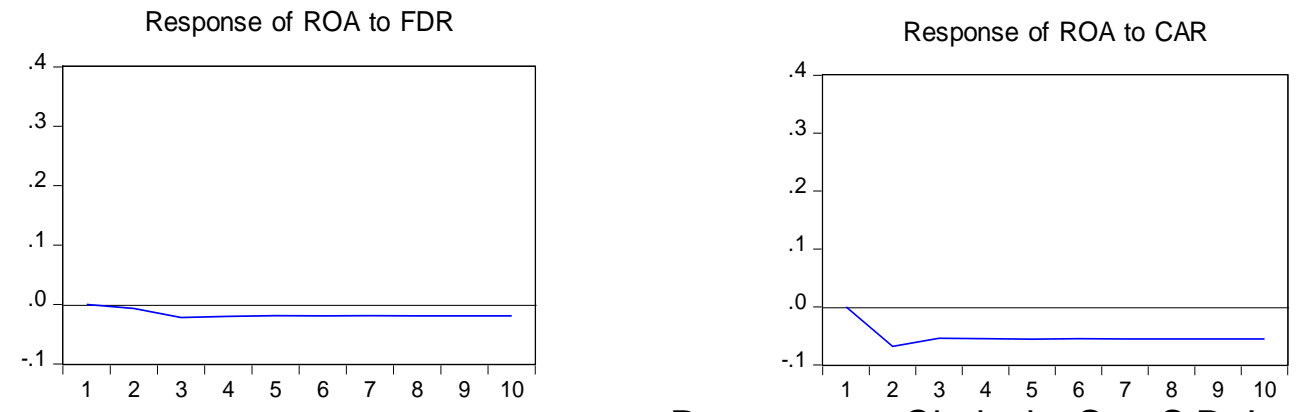

Response to Cholesky One S.D. Innovations

Response to Cholesky One S.D. Innovations
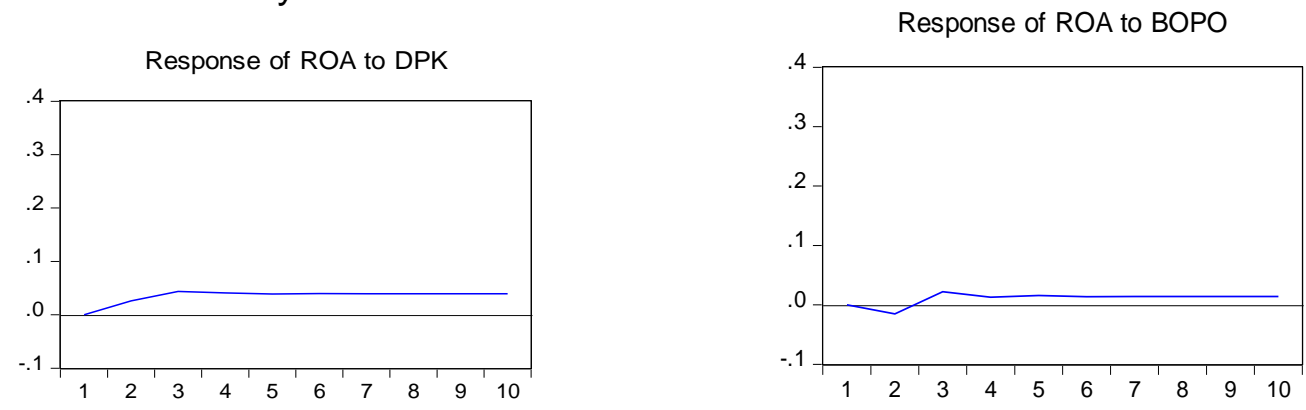

Response to Cholesky One S.D. Innovations

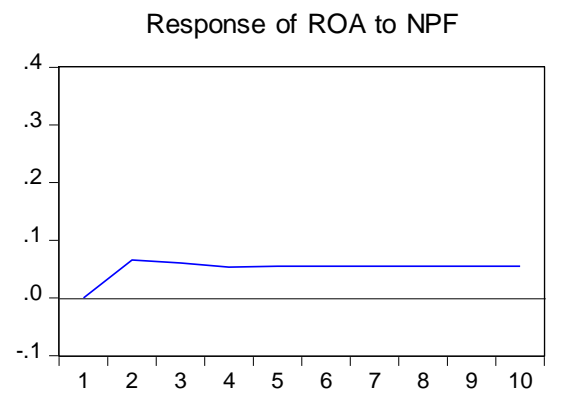

Respon negatif ROA terhadap goncangan yang terjadi pada CAR ditunjukkan pada bulan kedua dan respon negatif berlanjut pada bulan ketiga. Respon ROA mencapai posisi stabil mulai pada bulan keempat. Respon negatif ROA juga terjadi ketika ada goncangan pada FDR dan mencapai posisi stabil pada bulan keempat. Sementara itu ROA merespon positif ketika terjadi goncangan yang terjadi pada NPF, BOPO dan DPK. Respon ROA mencapai posisi stabil terhadap goncangan NPF pada bulan keenam. Sedangkan posisi stabil BOPO dan DPK

ketika ROA merespon kedua variabel tersebut terjadi pada bulan keempat.

Diantara empat variabel di dalam model, goncangan NPF cukup kuat di respon oleh ROA. Fluktuasi NPF perlu di waspadai oleh manajemen bank syariah dalam menentukan kebijakan perbankan karena fluktuasi NPF berpengaruh langsung terhadap fluktuasi ROA. Pembiayaan bermasalah menjadi bagian penting bagi strategi perbankan untuk mempertahan pendapatan yang diperoleh. Disamping itu, NPF yang tinggi akan mempengaruhi kepercayaan 
stakeholder terhadap kemampuan manajemen bank dalam mengelola likuditas. Oleh karena itu, goncangan NPF mendapatkan respon cukup tinggi oleh ROA dibanding dengan variabel lain.

\section{Forecast Error Variance Decomposition (FEVD)}

Variance decomposition (VD) untuk mengetahui kontribusi suatu variabel ROA, CAR, FDR, NPF, BOPO dan DPK terhadap perubahan ROA pada beberapa periode mendatang. Tabel 8, analisis VD menunjukkan bahwa variabel yang diperkirakan akan memiliki kontribusi paling besar terhadap ROA pada sepuluh bulan kedepan adalah ROA yang diikuti secara berturut-turut kontribusi FDR, CAR, NPF, DPK, FDR dan paling rendah adalah BOPO.

Respon negatif ROA terhadap goncangan yang terjadi pada CAR ditunjukkan pada bulan kedua dan respon negatif berlanjut pada bulan ketiga. Respon ROA mencapai posisi stabil mulai pada bulan keempat. Respon negatif ROA juga terjadi ketika ada goncangan pada FDR dan mencapai posisi stabil pada bulan keempat. Sementara itu ROA merespon positif ketika terjadi goncangan yang terjadi pada NPF, BOPO dan DPK. Respon ROA mencapai posisi stabil terhadap goncangan NPF pada bulan keenam. Sedangkan posisi stabil BOPO dan DPK ketika ROA merespon kedua variabel tersebut terjadi pada bulan keempat.

Diantara empat variabel di dalam model, goncangan NPF cukup kuat di respon oleh ROA. Fluktuasi NPF perlu di waspadai oleh manajemen bank syariah dalam menentukan kebijakan perbankan karena fluktuasi NPF berpengaruh langsung terhadap fluktuasi ROA. Pembiayaan bermasalah menjadi bagian penting bagi strategi perbankan untuk mempertahan pendapatan yang diperoleh. Disamping itu, NPF yang tinggi akan mempengaruhi kepercayaan stakeholder terhadap kemampuan manajemen bank dalam mengelola likuditas. Oleh karena itu, goncangan NPF mendapatkan respon cukup tinggi oleh ROA dibanding dengan variabel lain.

\section{Forecast Error Variance Decomposition (FEVD)}

Variance decomposition (VD) untuk mengetahui kontribusi suatu variabel ROA, CAR, FDR, NPF, BOPO dan DPK terhadap perubahan ROA pada beberapa periode mendatang. Tabel 8, analisis VD menunjukkan bahwa variabel yang diperkirakan akan memiliki kontribusi paling besar terhadap ROA pada sepuluh bulan kedepan adalah ROA yang diikuti secara berturut-turut kontribusi FDR, CAR, NPF, DPK, FDR dan paling rendah adalah BOPO.

Tabel 8. Hasil Uji Variance Decomposition

\begin{tabular}{cccccccc}
\hline Period & S.E & ROA & CAR & FDR & NPF & BOPO & DPK \\
\hline $\mathbf{1}$ & 0.345084 & 100.0000 & 0.000000 & 0.000000 & 0.000000 & 0.000000 & 0.000000 \\
$\mathbf{2}$ & 0.463847 & 95.40592 & 2.150029 & 0.021241 & 2.000295 & 0.109505 & 0.313014 \\
$\mathbf{3}$ & 0.568010 & 93.99728 & 2.338717 & 0.162361 & 2.478700 & 0.224003 & 0.798937 \\
$\mathbf{4}$ & 0.652877 & 93.56613 & 2.474741 & 0.215346 & 2.539370 & 0.208397 & 0.996015 \\
$\mathbf{5}$ & 0.728022 & 93.27632 & 2.575207 & 0.240735 & 2.610108 & 0.213405 & 1.084223 \\
$\mathbf{6}$ & 0.796081 & 93.08602 & 2.630808 & 0.260386 & 2.659793 & 0.207988 & 1.155005 \\
$\mathbf{7}$ & 0.858765 & 92.95050 & 2.675161 & 0.272129 & 2.694754 & 0.206240 & 1.201220 \\
$\mathbf{8}$ & 0.917182 & 92.84604 & 2.707326 & 0.282374 & 2.722226 & 0.204365 & 1.237667 \\
$\mathbf{9}$ & 0.972100 & 92.76532 & 2.732752 & 0.289781 & 2.742950 & 0.203206 & 1.265996 \\
$\mathbf{1 0}$ & 1.024071 & 92.70042 & 2.753068 & 0.295997 & 2.759772 & 0.202162 & 1.288583 \\
\hline
\end{tabular}


Dari hasil rata-rata persentase pada masing-masing variabel tersebut dapat diketahui bahwa NPF memiliki kontribusi terbesar disusul CAR, DPK, FDR dan terakhir adalah BOPO dalam mempengaruhi tingkat ROA pada bank syariah. Rendahnya kontribusi FDR dan BOPO terhadap ROA menunjukkan bahwa manajemen bank syariah kurang memperhatikan besaran FDR dan BOPO untuk menentukan kebijakan dengan tujuan meningkatkan ROA. Di lain pihak, manajemen bank syariah lebih memperhatikan besaran kontribusi NPF dan CAR dalam menentukan besarnya pendapatan untuk mempengaruhi tingkat ROA

Dilihat dari trend setiap periode pada variance decomposition menunjukkan bahwa trend kontribusi ROA terhadap ROA pada bulan pertama menunjukkan nilai $100 \%$ kemudian pada periode-periode berikutnya menunjukkan kecenderungan menurun. BOPO terhadap ROA juga menunjukkan kecenderungan menurun dari periode ke periode. Sedangkan kontribusi CAR, FDR, NPF dan DPK terhadap ROA menunjukkan trend positif atau meningkat dari periode ke periode. Kenyataan ini menunjukkan bahwa manajemen bank syariah melihat CAR, FDR, NPF dan DPF sebagai variabel yang aktif dalam mempengaruhi pergerakan ROA.

\section{Penutup}

Hasil penelitian menunjukkan bahwa dalam jangka panjang variabel CAR, FDR, NPF berpengaruh negatif terhadap tingkat ROA, sedangkan BOPO dan DPK berpengaruh positif terhadap ROA. Diantara lima variabel tersebut yang paling berpengaruh adalah BOPO disusul dengan FDR. Sedangkan variabel yang terendah mempengaruhi ROA adalah DPK, NPF dan CAR. Temuan ini menunjukkan bahwa manajemen sangat memperhitungkan tingkat kemampuan bank untuk mengelola CAR,
FDR, NPF, BOPO dan CAR untuk mempengaruhi ROA.

Hasil impulse response menunjukkan guncangan yang terjadi pada NPF, BOPO dan DPK direspon positif oleh ROA dan akan stabil dalam jangka waktu yang berbeda pada setiap variabel. Guncangan yang terjadi pada variabel lainnya seperti tingkat CAR dan FDR direspon negatif oleh ROA dan akan stabil pada periode yang berbeda. Sedangkan hasil dari variance decomposistion menunjukkan bahwa NPF memiliki kontribusi paling besar kemudian disusul CAR, DPK, FDR dan terakhir adalah BOPO dalam mempengaruhi besarnya pembiayaan. Kontribusi CAR, FDR, NPF dan DPK terhadap ROA menunjukkan trend positif sedangkan BOPO cenderung memiliki trend negatif

Dari hasil temuan penelitian ini dapat direkomendasikan bahwa penelitian berikutnya tidak hanya variabel kinerja keuangan bank syariah tetapi juga variabel pendapatan, inflasi, tingkat bunga, dan investasi dimasukkan sebagai penentu tingkat ROA.

\section{Daftar Pustaka}

Almunawwaroh, M \& Marliana, R, "Pengaruh CAR, NPF dan FDR terhadap ROA Bank Syariah di Indonesia, Amwaluna, Vol 2, No.1, 2018

Astohar, "Pengaruh CAR dan FDR terhadap ROA Perbankan Syariah di Indonesia dengan Inflasi sebagai Variabel Pemoderasi", Among Makarti, Vol. 9, No. 18, 2016

Azmi, A, "Analisis Pengaruh Rasio Kinerja Keuangan terhadap ROA Bank Permbiayaan Rakyat Syariah di Indonesia", Jurnal Akuntansi, Vo 12, No 1, 2018

Dwijayanthy, F \& Naomi, P. Analisis Pengaruh Inflasi, BI Rate, dan Nilai Tukar Mata Uang terhadap ROA Bank 
Periode 2003-2007., Karisma., Vol. 3, No. 2, 2009

Farrashita \& Prasetiono, "Pengaruh CAR, FDR, NPF dan BOPO terhadap ROA (ROE) pada Bank Umum Syariah di Indonesia," Diponegoro Journal of Management, Vol. 5, No. 1, 2016

Husaeni, U., A, "Analsis Pengaruh Dana Pihak Ketiga dan Non Performing Financing terhadap Return on Asset pada BPRS di Indonesia", Equilibrium, Jurnal Ekonomi Syariah, Vol. 5, No. 1, 2017

Kartikasari, M, "Penilaian Kinerja Keuangan Menggunakan Analisis Rasio pada Bank Mandiri di BEI", Jurnal Ilmu \& Riset Manajemen, Vol. 3, No. 11, 2014

Layaman dan Qoonitah Fitri Al-Nisa. "Analisis Pengaruh Capital Adequacy Ratio (Car) Dan Financing To Deposit Ratio (Fdr) Terhadap Profitabilitas Bank Syariah." Al-Amwal: Jurnal Ekonomi dan Perbankan Syari'ah 8.1 (2016).

Lemiyana \& Litriani, E, "Pengaruh NPF, FDR, BOPO terhadap Reurn on Asset (ROA) pada Bank Umum Syariah", IEconomic, Vol. 1, No. 1, 2016

Lutfiyah dan Dina, "Pengaruh Pertumbuhan Dana Pihak Ketiga Terhadap Laba Perbankan Syariah di Indonesia", JESTT, Vol.2 No.8, 2015

Linda \& Dina, "Pengaruh CAR, NPF, FDR, dan ROE terhadap ROA pada Bank Pembiayaan Rakyat Syariah di Indonesia Periode Januari 2009 hingga Mei 2014," JEST, Vol. 2, No. 12, 2015

Mawaddah, N, "Faktor-faktor yang Mempengaruhi ROA", Etikonomi, Vol. 14, No. 2, 2015

Muliawati, S \& Khoiruddin, M, "Faktor-faktor Penentu ROA Bank Syariah di Indonesia", Management Analysis Journal, Vol 4, No. 1, 2015
Munir, A.S, "Analisis Faktor-faktor yang Mempengaruhi Kinerja Keuangan Perbankan Syariah di Indonesia", Jurnal Ummul Qura, Vol 9, No. 1, 2017

Ningsukma \& Haqiqi, "Pengaruh Internal CAR, FDR dan BOPO dalam Peningkatan ROA Industri Bank Syariah di Indonesia," Jurnal Aplikasi Manajemen, Vol. 14, No.1, 2016

Nurhasanah, "Pengaruh Asset Growth dan Dana Pihak ketiga terhadap ROA Perbankan yang Listing di Bursa Efek Indonesia (BEI) dengan Kecukupan Modal sebagai Pemoderasi”, Jurnal Magister Akuntansi Pascasarjana Universitas Syiah Kuala, Vol 3. No.3, 2014

Rida \& Yuma, "Analisa Efisiensi Operasional terhadap ROA pada Bank Umum Syariah dan Unit Usaha Syariah pada BSM dan BNI Syariah," Jurnal Bisnis dan Manajemen, Vol. 4, No. 3, 2008

Riyadi. Banking Asset \& Liability Management. Jakarta; Lembaga penerbit Fakultas Ekonomi, Universitas Indonesia., 2004

Setyawati, I, Suroso, S, Rambe D \& Susanti, Y, " Peningkatan Kinerja Keuangan Melalui Manajemen Kesehatan pada Bank Syariah di Indonesia" Jurnal Ecodemica, Vol.1, No 1, 2017

Sudarsono, H, "Analisis Pengaruh Kinerja Keuangan terhadap ROA Bank Syariah di Indonesia", Economica; Jurnal Ekonomi Islam, Vol 8, No. 2, 2017

Sudarsono, H, Bank dan Lembaga Keuangan Syariah, Deskripsi dan Ilustrasi, Yogyakarta, Ekonesia, 2014

Syawal, H, Rasio Keuangan dan Pengaruhnya Terhadap ROA pada Bank Pembiayaan Rakyat Syariah di Indonesia, Esensi: Jurnal Bisnis dan Manajemen, Vol. 7, No. 1, 2017 
Ubaidillah, "Analisis Faktor-faktor yang Mempengaruhi ROA bank Syariah di Indonesia", El Jizwa, Jurnal Ekonomi Islam, Vol. 4, No. 1, 2016

Ummah \& Suprapto, "Faktor-Faktor Yang Mempengaruhi ROA Pada Bank Muamalat Indonesia", Jurnal Ekonomi dan Perbankan Syariah, Vol. 3. No.2, 2011

Wati, R. M \& Ngumar, "Analisis Faktorfaktor yang Mempengaruhi Kinerja Keuangan Bank Mandiri Syariah", Jurnal Ilmu dan Riset Akuntansi, Vol. 5, No.8, 2016 